\title{
MODELING OF OZONE DUE TO WEATHER CONDITIONS
}

\author{
SOUZA, Amaury - amaury.de@uol.com.br \\ PAVÃO, Hamilton Germano \\ OLIVEIRA, Ana Paula Garcia \\ Universidade Federal de Mato Grosso do Sul, Instituto de Física
}

\begin{abstract}
Ozone concentrations are valuable indicators of possible health and environmental impacts. However, they are also used to monitor changes and trends in the sources of both ozone and its precursors. For this purpose, the influence of meteorological variables is a confusing factor. This study presents an analysis of 4 year of ozone concentrations measured in a Campo Grande-MSBrazil city. Firstly, the aim of this study was to perceive the daily, monthly and seasonal variation patterns of ozone concentrations. Diurnal cycles are presented by season and the fit of the data to a normal distribution is tested. In order to assess ozone behavior under weather conditions, local meteorological variables (wind direction and speed, temperature, relative humidity and rainfall) were monitored together with ozone concentrations. The main relationships we could observe in these analyses were then used to obtain a regression equation linking diurnal ozone concentrations with meteorological parameters. The developed model is capable of explaining over $70 \%$ of the variability in the ozone concentrations

Keywords: Urban ozone; Campo Grande; Meteorological parameters.
\end{abstract}

\section{MODELAGEM DE OZÔNIO DEVIDO ÀS CONDIÇÕES METEOROLÓGICAS Resumo}

Estudos sobre a influência da poluição atmosférica na qualidade de vida do ser humano têm sido realizados com grande intensidade nos últimos anos. O objetivo desta pesquisa foi de desenvolver um modelo para prever as concentrações de ozônio em função das variáveis meteorológicas. As medidas de concentração do ozônio foram realizadas na Universidade Federal de Mato Grosso do Sul. Foram utilizados dados do período de 2004 a 2008. As variáveis preditoras referentes ao clima (umidade relativa, velocidade do vento, precipitação diária e temperatura) foram cedidas pela EMBRAPA-GADO de CORTE-Campo Grande-MS. As principais relações observadas nestas análises foram então usadas para obter uma equação de regressão que liga as concentrações de ozônio diurnas com parâmetros meteorológicos. O modelo desenvolvido é capaz de explicar mais de $70 \%$ da variabilidade nas concentrações de ozônio de superfície.

Palavras chaves: ozônio urbano; Campo Grande; parâmetros meteorológicos.

\section{Introduction}

Increased tropospheric ozone concentrations are currently a matter of large concern. Since the beginning of this century, it is obvious that background ozone concentrations have more than doubled (VOLZ AND KLEY, 1988; STAEHELIN AND SMITH, 1991; RYDLEY, 1991; STAEHELIN et al., 1994). The assessment of ozone levels is extremely important since ozone is a key element to control the chemical composition of the troposphere and climate as it is also a greenhouse gas. The presence of ozone in the troposphere is understood to arise from two basic processes: (i) tropospheric y stratospheric exchange that causes the transport of stratospheric air, rich in ozone, into the Troposphere; and (ii) production of ozone from photochemical reactions occurring within the Troposphere. The production of ozone in the Troposphere is accomplished through a complex series of reactions referred to as the 'photochemical smog mechanism'. Urban air pollution in many cities is currently an issue of great concern to the general public maintaining a high profile on the political agenda. The reality of numerous situations in which the near-surface ozone concentration exceeds the adopted threshold values, has attracted considerable 
public attention due to the well-known harmful impact on biosphere, human health, animal populations, agriculture productivity and forestry (SCHENONE AND LORENZINI, 1992; BRAUER AND BROOK, 1997).Despite the concern, little is known about the mechanisms of chemical transformation and transportation of air pollutants within the complex geometry of an urban environment.

Although ozone chemistry has been extensively investigated in many chamber experiments and in photochemical modeling studies, there are still significant difficulties in predicting accurately ambient ozone levels, as well as its spatial distribution, behavior and associated trends. It is believed that there are more parameters than just precursor concentrations that lead to ozone formation $y$ destruction processes in the air.

To track and predict ozone, one must create an understanding of not only ozone itself but also the conditions that contribute to its formation. It is necessary to apply models that describe and understand the complex relationships between ozone concentrations and the many variables that cause or hinder ozone production. Some other factors, such as regional transport of ozone and its precursors, can affect ozone levels. Ozone concentrations are strongly linked to meteorological conditions. In addition, favorable meteorological conditions (clear skies, warm temperatures and soft winds) have a great influence on ozone concentrations (VECCHI AND VALLI, 1999). Land-sea breezes also influence ozone concentrations at coastal sites. In Europe, the highest ozone concentrations take place in summer under stable high-pressure systems with clear skies. During these episodes, ozone levels well above the international guidelines (WHO, 1988; UN-ECE, 1988) have been observed in large areas and ozone concentrations of $100-150 \mathrm{ppb}$ may last for several days. The situation in the Mediterranean area is as follows (MILLÁN et al., 1991, 1996). The ozone threshold of the European Union directive for damages to human health (120 $\mathrm{mg} / \mathrm{m}^{3}, 8 \mathrm{~h}$ average) exceeded systematically for at least 4 months of the year, and the one for the information to the population (180 mg my3, hourly average) can also be exceeded frequently from April to August. The one for the vegetation ( $65 \mathrm{mg} / \mathrm{m}^{3}$ as a $24-\mathrm{h}$ average) was exceeded systematically for more than 6 months of the year. Several experts have recognized that abatement strategies are required to decrease the ozone surface levels observed (BUILTGES et al., 1988; HECK, 1989). Nevertheless, all of them agree that such measurements can only be proposed after improving the current state of the art in the main parameters involved in the formation of photochemical oxidants. This is particularly important in Spain, where the experimental evidence of oxidants and precursors is very limited (ZURITA AND CASTRO, 1983; MILLÁN et al., 1991; SÁNCHEZ AND SANZ, 1994).

For Brazil, according to Resolution 003 of the 1990 NATIONAL COUNCIL ON THE ENVIRONMENT-CONAMA, the primary and secondary standard is $160 \mathrm{ug} / \mathrm{m}^{3}$ or about $81.2 \mathrm{ppb}$.

Urban ozone formation is a complex phenomenon since this pollutant is not emitted into the atmosphere directly but it is produced thanks to the interaction of meteorology, NOx and VOCS (FINLAYSON-PITTS AND PITTS, 1986; SAUNDERS et al., 1991). Therefore, several surveys have tried to assess the impact of meteorological factors taking into consideration ozone levels in order to detect changes in ozone precursor emissions (KORSOG AND WOLFF, 1991; BLOOMFIELD et al., 1996; COX AND CHU, 1996; DAPENG et al., 1996; PRYOR, 1998). 
The work reported in this paper is an investigation into the importance of meteorology in determining surface ozone concentrations, and deals with the use of linear regression method for predicting ozone concentrations as a function of meteorological parameters. The study focuses on the impact of meteorological parameters on ozone variability at an urban in the city of Campo Grande (with a population of approx.724 000 spread over an area of $8096 \mathrm{~km}^{2}$ ). From January 2004 to December 2008. The campaign was aimed at studying ozone concentrations and the influence of the most relevant meteorological variables where precursor emissions.

\section{METHODS}

The city of Campo Grande, MS (20 27'16 "S, 54 47'16" W, 650 m), is located on the plateau called Campo Grande-Maracaju $150 \mathrm{~km}$ to the start of the largest floodplain in the world, Pantanal $\left(139,111 \mathrm{~km}^{2}\right.$ area) (Figure 1). The climate in the region of Campo Grande has moderate temperatures ranging from $17.80 \mathrm{C}$ minimum, maximum and average $29.8^{\circ} \mathrm{C} 22.7^{\circ} \mathrm{C}$, with well-distributed rainfall and hot summer, the average relative humidity of air is $72.8 \%$, with prevailing winds from the East in Campo Grande, MS, occurring from north in the months January to December, which resulted in annual values $24 \%$ Eastern, $19.8 \%$ and $12.2 \%$ of North Northeast, and the lulls represented $12 \%$, with an average speed of $3.1 \mathrm{~m} \mathrm{/} \mathrm{s}$, and average monthly rainfall of $122.4 \mathrm{~mm}$ and annual average of $1469 \mathrm{~mm}$ (SOUZA, 2009).

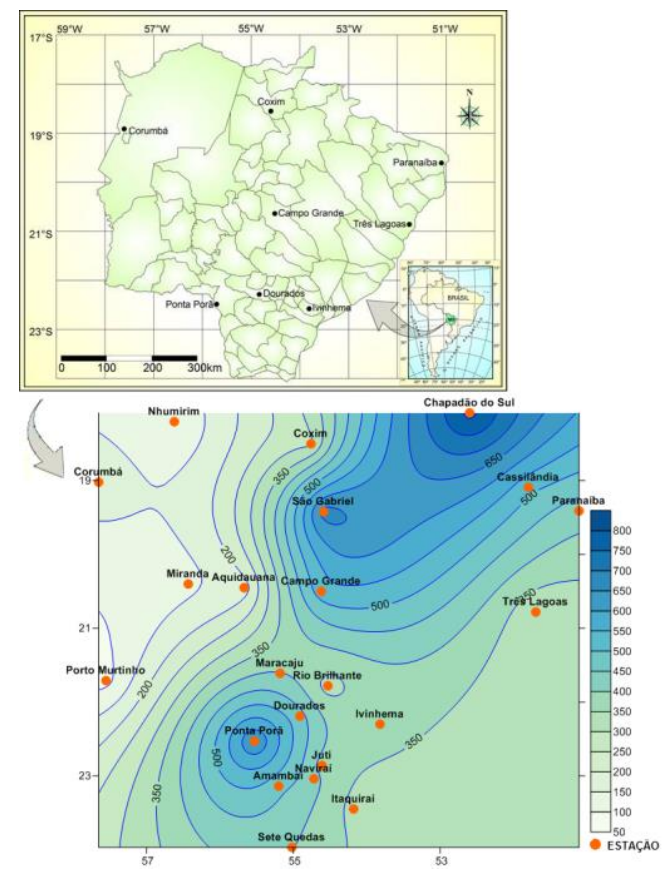

Figure 1 - Location Space, latitude, longitude, altitude of the city of Campo Grande, MS Brazil used in this study.

Information about daily levels of ozone $\left(\mathrm{O}_{3}\right)$ were obtained from the Department of Physics of UFMS. The ozone analyzer used for the measurements has the working principle of the absorption of ultraviolet radiation by ozone molecule. 
These measurements are performed continuously 24 hours a day, every 15 minutes are given values of ozone concentration. The analyzer is installed in the vicinity of Campo Grande, away from local sources. Next, the arithmetic mean was calculated per day, it was assumed that this estimate was representative of air pollution in the city of Campo Grande (GOUVEIA et al., 2004). Information on rainfall, maximum temperature, wind speed and relative humidity were obtained from Embrapa - Brazilian Beef Cattle , Campo Grande.

In this study we performed a descriptive analysis of variables and, subsequently, were associated with ozone concentration data, the climatic variables rainfall, maximum temperature, relative humidity and wind speed, for the period 2004 to 2008 .

To assess how meteorological conditions affect variations in ozone levels, the authors used multiple linear regression analysis. This is one of the most widely used methods for predicting how ozone concentrations depend on meteorological factors. The general equation for the model was as follows:

$Y=\beta_{0}+\beta_{1} X_{1}+\beta_{2} X_{2}++\ldots+\beta_{k} X_{k}+\varepsilon$

where is an objective variable (ozone concentrations); is the number of independent variables (meteorological variables); are independent variables; are regression coefficients (estimated using the least squares procedure); is an error term associated with the regression analysis.

The Mean Standard Error (MSE) was used after equations were linearized to check predicting hospital admissions:

$\mathrm{EQM}=\sqrt{\frac{1}{n}}\left(\sum_{i=1}^{n}(P i-O i)^{2}\right)$

where $P i$ is the admissions estimate, $O i$ is the admissions that actually occurred and $n$ is the sample.

All analyses were carried on using SPSS 10.0 at a 5\% significance level.

\section{Results and discussion}

Table 1 presents the descriptive statistics for daily levels of air pollutants (ozone), precipitation, maximum air temperature, relative humidity, air velocity.

\begin{tabular}{|c|c|c|c|c|c|c|c|}
\hline variables & Registry & Mean & standard & Minimum & Median & maximum & trend \\
\hline Precipitação & 1827 & & & 0,0 & 0,0 & 97,8 & growing \\
\hline Ozone & 1827 & $\begin{array}{l}3,6 \\
17,8\end{array}$ & $\begin{array}{l}9,6 \\
8,7\end{array}$ & 0,7 & 16,2 & 52,8 & growing \\
\hline temperature & 1827 & 30,1 & 3,8 & 11,1 & 30,7 & 39,5 & growing \\
\hline Humidity & 1827 & 65,7 & 16,4 & 19,1 & 67,0 & 98,0 & stationary \\
\hline Velocity & 1827 & 3,7 & 1,7 & 0.0 & 3,4 & 11,1 & growing \\
\hline
\end{tabular}

Table 1: Descriptive statistical analysis of daily weather variables

The $\mathrm{O}_{3}$ is formed more frequently in winter and spring, but at other times of year it is also possible to their training. The maximum value reached by $\mathrm{O}_{3}$ this 
series was ppb and $52.8 \mathrm{ppb}$ and minimum $0.7 \mathrm{ppb}$. The mean and median values were very $(17.8 \pm 8.7) \mathrm{ppb}$ and $16.2 \mathrm{ppb}$. This was measured pollutant 1827 days, and during the study period has not exceeded the standard air quality $(80 \mathrm{ppb})$ (Table 1$)$.

During the period, the ozone concentration measurements were performed continuously. The equipment used for these measurements was an ozone analyzer. This analyzer was installed around the city of Campo Grande-MS, a region far from the urban area and therefore free from interference from automobiles and industries. Although we performed measurements of ozone concentration for each month of 2004, 2005, 2006, 2007, 2008 we will present results of the hourly averages of the years in order to show the different behavior of the concentration of ozone to the time of the year. Figure 2 below shows the hourly variation of average ozone concentration for the years 2004 to 2008 .

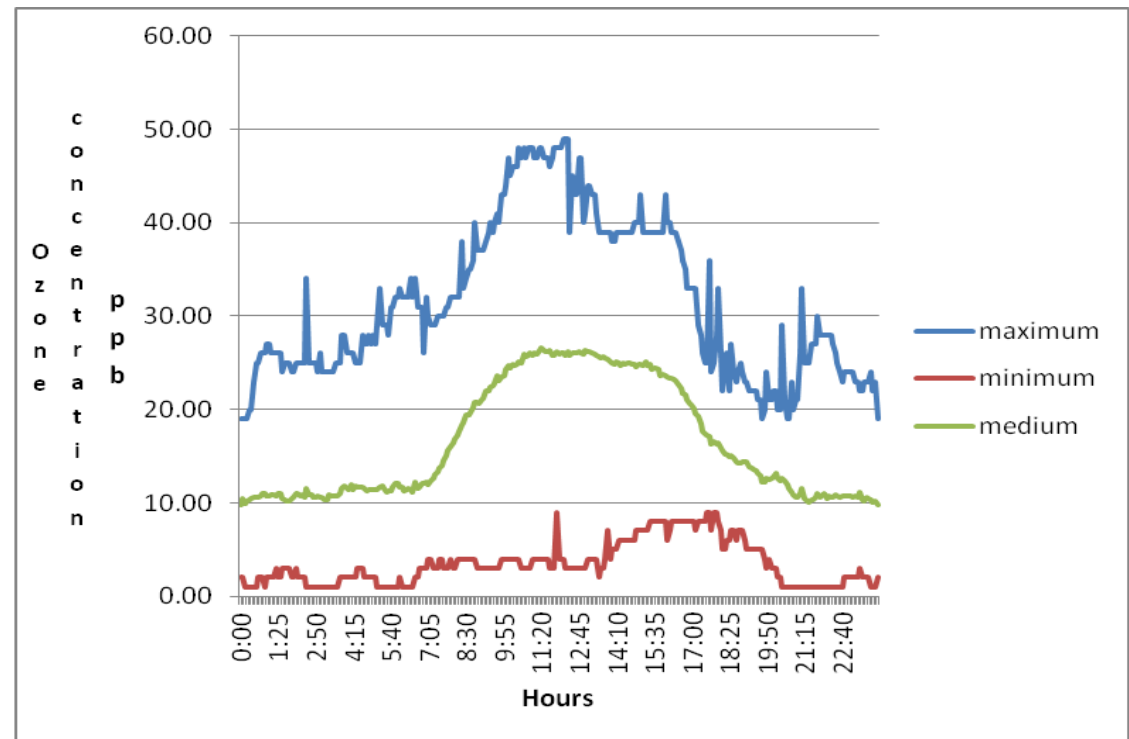

Figure 2: Average hourly concentration of ozone - years 2004 to 2008.

As shown in Figure 2 we can see that the concentration of ozone has the following behavior: maxima during the day, reaching its maximum value between $11 \mathrm{~h}$ and $15 \mathrm{~h}$ and minimum values at night. The average concentration of ozone is $17.38 \pm 5.32 \mathrm{ppb}$, with the maximum value of $49.00 \mathrm{ppb}$ at $12: 15 \mathrm{~h}$, and the minimum value of $1.00 \mathrm{ppb}$ in the early hours.

The average concentration of ozone can vary greatly from one day to another, because, depending on cloud cover and climatological factors, we can have an increase or decrease in concentration of ozone.

This lack of constancy or linearity is related to climatic conditions of the day. The daily variations of ozone concentration depend solely on weather conditions, such as cloud cover, solar radiation, rain and wind.

It is known that on sunny days, the ozone concentration is higher, because the more radiation passes through the atmosphere, the greater the photochemical reactions that produce ozone. We note that in the days that the minimum values were concentrations coincided with the days when there was the highest rainfall 
for the respective month. This fact is related to that during a rainy day, because of cloud cover, there is a reduction in ultraviolet radiation reaching the surface and therefore a decrease in photochemical reactions are responsible for production of ozone.

The wind is also a factor that influences the concentration of ozone, because it takes chemical species from one region to another, thus regions that do not pollute, may also suffer from high concentrations of ozone.

Meteorology plays an important role in ozone formation and transport. As a result, substantial variations in meteorological conditions (in all time scales) can exert such a large impact on zone concentrations that they mask long-term trends in ozone that could reasonably be traced to changes in precursor emissions such as NOx. and VOCs. On the other hand, as found in many studies, certain meteorological conditions are required for the formation and accumulation of high concentrations of $\mathrm{O}_{3}$ (COLBECK AND MACKENZIE, 1995 and references therein). These conditions often include a well-defined boundary layer, subsidence inversion, light winds, high temperatures and high solar radiation.

Under this assumption, we have carried out a survey to assess the behavior of ozone concentration in surface air with several meteorological variables available. The analysis focuses on studying dependencies of ozone concentration levels and different meteorological parameters. Our aim was to identify the variables with the higher impact on ozone concentrations under weather conditions, have used average hourly values from meteorological data. The selected variables were as follows: temperature $\left(T\right.$, expressed in $\left.{ }^{0} \mathrm{C}\right)$, relative humidity $(H$, expressed in $\%)$, Wind speed $(v$, expressed in $m / s)$, and rainfall $(r$, expressed in $\mathrm{mm}$ ).

In order to find the meteorological factors influencing ozone concentration and to assess them in order of importance, a regression analysis was carried out with the SPSS 10.0 software.

First of all, we carried out a simple regression on ozone concentrations and some meteorological factors available. This study was carried out taking into consideration: (1) all data. In Table 2, Pearson correlation coefficients (BUNZL, 1993) between ozone concentration and these meteorological parameters are summarized.

Looking at the coefficients, it can be seen that temperature, wind speed and relative humidity are the most important meteorological factors influencing the variation in ozone levels. The importance of temperature and wind speed is discussed in the following sections. Relative humidity is also important because this variable may play a role in the overall reactivity of the system, either by affecting chain termination reactions or in the production of wet aerosols, which in turn affect the ultraviolet actinic flux. Furthermore e, humidity is considered to be a restrictive factor in the disposition of $\mathrm{NO}_{2}$ because high percentages of humidity favour the reaction of the $\mathrm{NO}_{2}$ with particles of $\mathrm{NaCl}$, very common in coastal places (VERA et al., 1997). There is a negative correlation between these data and relative humidity. 


\begin{tabular}{lcc}
\hline Ozone & $\mathrm{R}$ & $\mathrm{p}$ \\
precipitation & -0.373 & 0.0023 \\
$\begin{array}{l}\text { Maximum } \\
\text { temperature }\end{array}$ & 0.2457 & 0.0484 \\
relative humidity & -0.4721 & $<0.0001$ \\
Velocity & 0.579 & $<0.0001$ \\
\hline
\end{tabular}

Table 2- Correlation studies between ozone concentrations and the main meteorological variables

Values of Pearson $(r)$ coefficients are given together with the associated correlation probabilities $(P)$.

Table 2 presents the Pearson correlation coefficients of ozone concentration and in relation to meteorological variables. It is observed an inverse relationship between precipitation, air temperature and relative humidity.

The relationship between ozone concentration and temperature can be explained on theoretical grounds. Temperature plays an enhancing role in the propagation rate of the radical chain, and has an opposite effect on the termination rate of these chains (RUIZ-SUÁREZ et al., 1995). The evolution of ozone concentration with temperature can be seen in Fig.2, where it can be observed that the evolution of both variables is similar. This behavior remains unaltered until June and an increase in the temperature can be observed in July, august and September, also with an increase in the concentration of ozone by the effect of fire during this period for the preparation of the soil for plant at this time.

Table 1 show the meteorological variables, precipitation $(\mathrm{mm})$, maximum temperature $\left({ }^{\circ} \mathrm{C}\right)$, relative humidity $(\%)$ and wind speed $(\mathrm{m} / \mathrm{s})$. The lowest value recorded in the data series with respect to temperature was $11.1^{\circ} \mathrm{C}$ to maximum temperature. With respect to the highest value recorded was 39.5 in the series to the maximum temperatures. These are the extremes of temperature found in the series. For the variable relative humidity minimum and maximum values were 19.2 and $98 \%$. Rainfall in this data series, had values ranging from 0.0 to $97.8 \mathrm{~mm}$ and wind speed with a minimum value from 0 to $11.1 \mathrm{~m} / \mathrm{s}$.

High relative humidity and wet and rainy weather are usually associated with low ozone concentrations due to a reduction of photochemical efficiency and an increase of ozone deposition on water droplets (LELIEVELD AND CRUTZEN, 1990; DI CARLO et al., 2007). It is well known that relative humidity is negatively correlated with temperature, which can be considered as one of the primary ozone predictors. Ambient humidity affects the minimum temperature via two mechanisms (HUBBARD AND COBOURN, 1998). Firstly via the absorption of long-wave radiation emitted by the earth that would otherwise, under dry and cloudless conditions, be lost to space and secondly via the release of the latent heat of condensation as the sensible temperature falls to the dew point. High values of ozone concentrations are associated with low relative humidity values $(R=-0.47)$.

According to Lima et al. (1996), the air circulation on the South America significantly modifies the winter season for summer, especially at high levels (250hPA), as seen in Figure 3, comparing the patterns of movement tropospheric climate these two stations, at low (850hPA) and at high levels 
(250hPa). At low levels, the flow pattern does not change significantly from summer to winter (Figures $3 b$ and $3 a$ ). In winter, there is the center of the South Atlantic Subtropical Anticyclone (SASH) closest to the South American continent intensifying winds on the northeast coast of Brazil, located further east in the summer. At high levels, in winter, the flow pattern is zonal, with an anticyclonic circulation in the northwest of South America, whose center is positioned at approximately $5^{\circ} \mathrm{S}$, and the jet stream from west is quite intense, with the center of maximum speed the order of $45 \mathrm{~m} / \mathrm{s}$, located between $20^{\circ} \mathrm{S}$ and $40^{\circ} \mathrm{S}$. The main characteristics of the flow at high levels in summer are having a wavelike pattern over and present a strong anticyclonic center of Bolivia, known as the Bolivian high.

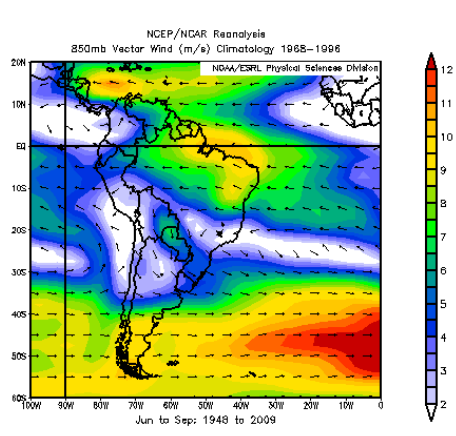

a)

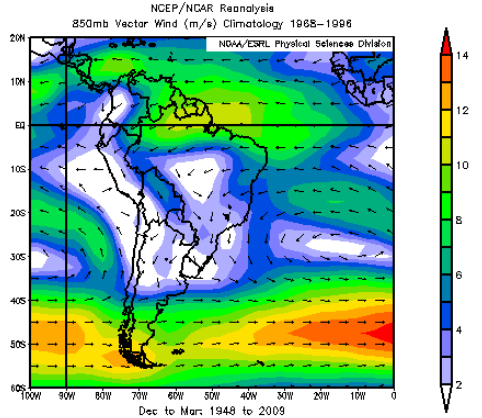

c)

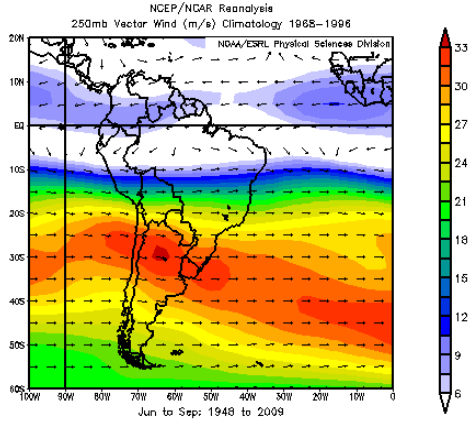

b)

d)

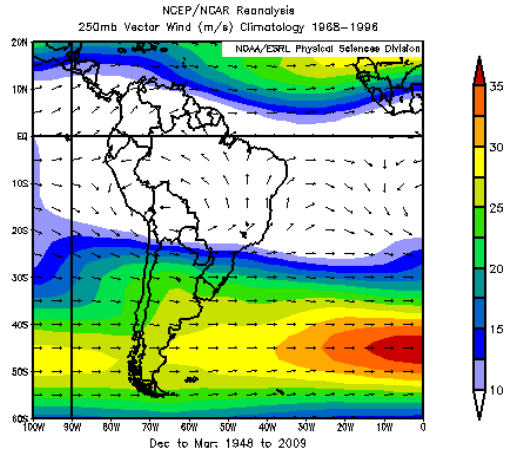

Figure 3 - Field of winds at $850 \mathrm{hPa}(\sim 2 \mathrm{~km})$ and 250hPa $(\sim 10 \mathrm{~km})$ on America South for $A$ and $C$ - Winter $B$ and $D$ - summer.

Source: NCEP / NCAR Reanalysis.

Observational studies suggest that the development of the Bolivian high in summer is associated with strong heating of the Earth's surface on the Bolivian Altiplano during this time of year, tropospheric heating the column and thereby producing an increased thickness atmospheric over land at this point, thus generating a cyclone at high levels. Furthermore, the moisture convergence at low levels of air masses from the wet north / northeast (Amazon region) and east (Pantanal) strengthen the convection and hence the release of latent heat of condensation in the middle and upper troposphere (FISCH et al., 1998), increasing precipitation over the Amazon region and the central part of Brazil and feeding the anti-cyclone high pressure the Bolivian high. Opposite 
conditions occur in winter, when this region of upward motion over the Amazon in summer migrates to the northwest of the South American continent, being situated on Venezuela and Colombia in May and June.

This work is in the larger interest of wind speeds at low altitude $(850 \mathrm{hPa})$ winds from the north that are stretching along the Andes from northern Peru through Brazil to the east of Bolivia into the Prata basin. These jet streams that cross the region of Mato Grosso do Sul - Campo Grande have an important role in modulating rainfall during the summer (FEARNSIDE et al. 2004) and transport of pollutants during the winter (AIRES et al. 2001).

In summer, the region is dominated by the surface Chaco Low and the Bolivian High at high levels. These systems coupled dynamically move northward during the winter. The dry winter season typically has milder temperatures due to the frequent invasion of cold air masses originating in the extratropical areas to the south. The squall lines occur in summer, associated with low levels of convergence, as in winter, anticipating the penetration front (VIANELLO \& ALVES, 1991).

During the summer, the region of Campo Grande receives winds from the north of systems that form over the Amazon region primarily a result of the convergence of trade winds from the northeast. In winter, the movement occurs to the west, toward the continent from the Atlantic Subtropical Anticyclone and the offset to the north Intertropical Convergence Zone moisture moving into remote areas to the north and northwestern Amazonia. The Hadley cell with ascending branches / convection in the Intertropical Convergence Zone and descending branches / subsidence in Central Brazil configure a weather situation of large-scale subsidence over the South American continent. This subsidence is characterized as a downward vertical movement of air masses above that inhibit the formation of clouds. These phenomena are responsible for the lack of rain and the definition of the dry season in Central Brazil (VIANELLO \& ALVES, 1991).

Regarding the percentages of occurrence of daily doldrums and intensity of winds at the surface, it appears that between August, September and October there were the lowest and highest values, respectively. This is explained by the higher frequency input air mass polar promoting a greater variation in pressure gradients. This fact reduces the residence time of particles in the atmosphere, thus increasing the possibility of burning the increase in oxygen flow. The distribution of the directions of the winds at 10 meters is present predominant direction of north and northeast. 
4a)

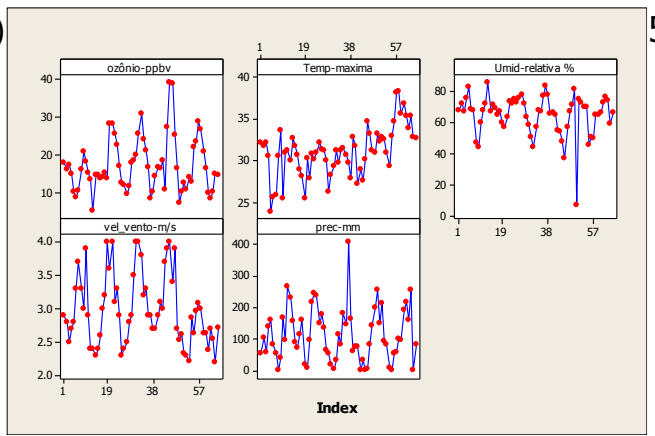

$5 a)$

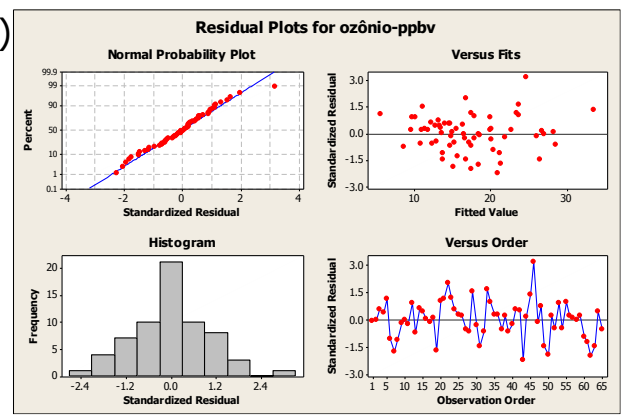

Figure 4 a) - Seasonal variation in the concentration of ozone $\left(\mathrm{O}_{3}\right),{ }^{0} \mathrm{C}$ maximum temperature, relative humidity $(\%)$, wind speed $(\mathrm{m} / \mathrm{s})$, precipitation $(\mathrm{mm})$ to Campo Grande-MS.

Figura 5 a) - Graphics and residual values of deviations observed in terms of adjusted values, the histogram of the response variable for the model of ozone concentration.

If the data are correlated, to adjust the model taking into account these self correlation. This correction is made by insertion of the model residue. All considerations of temporal trends should be observed when performing a study, for example, the impact of a given climatic factor in the concentration of ozone.

After considering the factors mentioned above, we find the values of the coefficients $\beta$ 's. the equation:

The overall regression equation for the years 2004 to 2008 is:

Ozone -ppbv $=-50.1+1.29$ Temperature -0.0057 humidity +9.79 vel 0.0129 prec.

(p) $=<0.0001$

Coef. of multiple determination (R2yy) $=0.6115$

Coef. multiple correlation (Ryy) $=0.7820$

$\mathrm{EQM}=4,4$

To evaluate the fit of the model must perform an analysis of the waste. This analysis can be by the graph of the residual variances of each observation in relation to the values adjusted by the model. A model has set and the graphic with the points closest to zero in the range -2 and 2 (Figure 5). Another chart that is also a good indicator of model fit is the graph of the observed values of the response variable in relation to the values set by the model. The points of this graph should be close, indicating that the fitted values are close to observed values (Figures 4 and 5) (TADANO et. al., 2009).

Figure 6 shows the observed and estimated using the model proposed by the regression equation (1) with an estimation error of $4.39 \%$. It is found that the normal distribution to be valid one has to observe a straight line, as evidenced in Figure 4, thus the equation 1 is satisfactory to explain the ozone concentration as a function of meteorological data. 


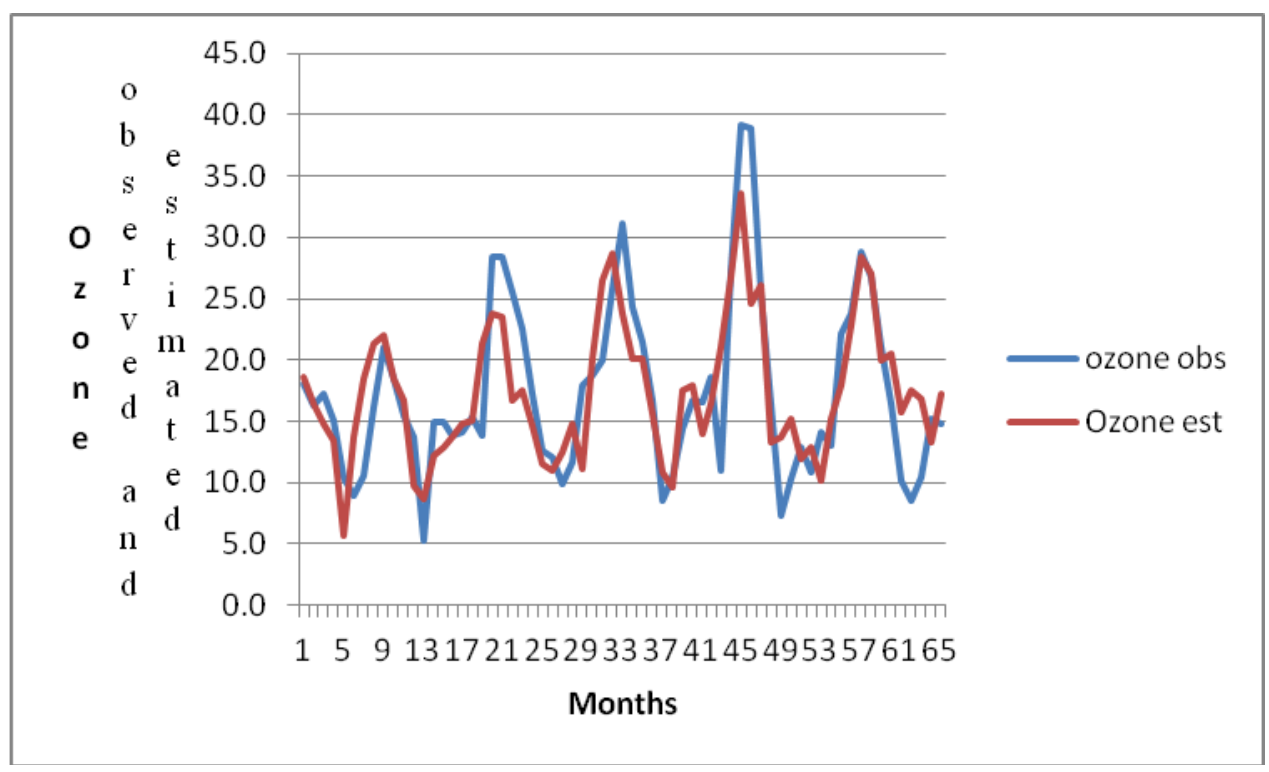

Figure 6 - Concentration of ozone observed and estimated by the model years 2004 to 2008 in Campo Grande.

Analysis for the months January, February and March (summer) (Figure 7A) the regression equation is:

ozone $=3.9+0.173$ temperature +0.0107 humidity +2.65 velocity -0.0298 precipitation

$(p)=0.0275$

Coef. of multiple determination (R2yy) $=0.5436$

Coef. multiple correlation (Ryy) $=0.7373$

$\mathrm{EQM}=4.07$

Analysis for the months April, May and June (autumn) (Fig. 7B) the regression equation

ozone $=42.5+0.038$ temperature -0.406 humidity -0.84 velocity +0.0119 precipitation

$(p)=0.0578$

Coef. of multiple determination (R2yy) $=0.5676$

Coef. multiple correlation (Ryy) $=0.7534$

$\mathrm{EQM}=1,93$

Analysis for the months July, August and September (winter) (Figure 7C) the regression equation is:

ozone $=-103+2.52$ temperature +0.079 humidity +12.0 velocity +0.0520 precipitation

$(p)=0.0114$

Coef. of multiple determination (R2yy) $=0.6658$

Coef. multiple correlation (Ryy) $=0.8160$

$\mathrm{EQM}=4,8$

Analysis for the months October, November and December (Figure 7D) the regression equation is:

ozone $=-24.5+0.972$ temperature -0.167 humidity +9.09 velocity -0.0111 precipitation 
$(p)=0.0768$

Coef. of multiple determination (R2yy) $=0.5389$

Coef. multiple correlation (Ryy) $=0.7341$

$\mathrm{EQM}=4,18$

A)

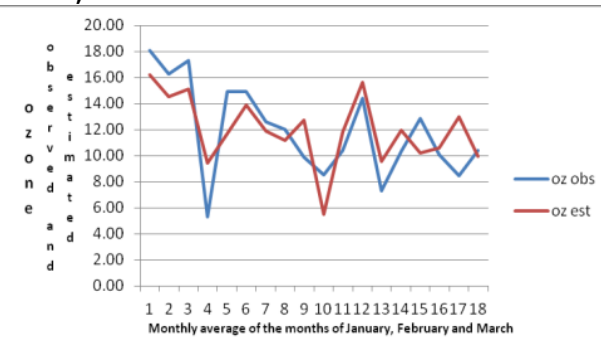

C)

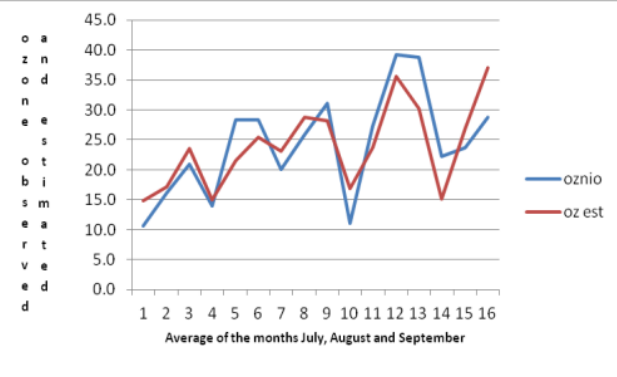

D)

B)
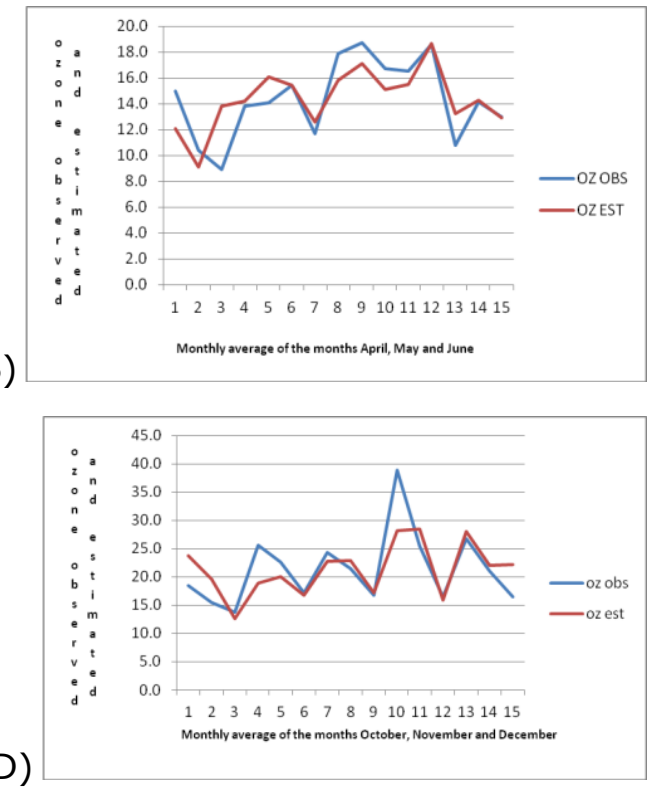

Figure 7 A, B, C, D - ozone concentration observed and estimated for the seasons of the year for the model years 2004 to 2008 in Campo Grande.

According to the multivariate linear regression, the model of ozone concentration, throughout the course of analysis, remained stable.

We performed t-tests (based on the Student's - $t$ distribution) to test the significance of the coefficients in the equations. The results show that the regression coefficients for temperature, humidity, precipitation and wind speed are statistically significant. The values for both coefficients are less than.05 ( $p$ value $<0,5)$. The ozone concentrations predicted by the statistical regression equation were plotted against the observed values, as shown in Figure 7. The results of the high correlation from this analysis indicate that ozone concentrations are strongly affected by meteorological conditions. During summer, about (Ryy) $=74 \%$, autumn $($ Ryy $)=75 \%$, winter (Ryy) $=81 \%$ and primavera (Ryy) $=73 \%$.

\section{Conclusion}

A approach was used to explore the complex relationship between ozone and other variables based on ambient air monitoring measurements. The results offer an insight into the dependence of ozone concentrations and meteorological conditions. It was found that the models' predictions and the real observations were consistent. The relative importance of the various input variables was also investigated. The results indicated the dependence of ozone concentrations and on meteorological conditions. It was determined that relative humidity, temperatureis the meteorological parameter with the highest contribution to ozone variations. 
We can conclude that the modelo de regressão can be used in modelling and predicting the ground level concentrations of ozone. Clearly, this study has indicated the potential of the approach for capturing the non-linear interactions between ozone and other factors and for the identification of the relative importance of these factors. modelling, therefore, provides a simple means of modelling and analysis of air pollutants and could be used in conjunction with other methods. Finally, it is important to note that the rate of formation of ozone is a function of the nature of the hydrocarbon molecule. Hydrocarbons differ in their rate of interaction with the $\mathrm{NO}_{2}$ photolytic cycle. Therefore, the training and testing sets used for the independent input parameters could, in principle, be substantially improved by specific hydrocarbon measurements. It would also be particularly interesting to observe the ranking of the variables and to determine whether the ranking of the variables remains constant when the selected hydrocarbon species are included as independent input parameters for the modelo approach. Therefore, it is recommended that the effect of selected hydrocarbon species should be examined in future studies. Research should also be directed towards elaborating on the effect of other meteorological data when they are added as input to the model. For example, what is the dependence of ozone concentration when the inversion layer is used as an input to the model?

The developed model is capable of explaining over $70 \%$ of the variability in the observed ozone concentrations. Its reliability was evaluated against observational ozone data with the calculation of several statistical indexes. All the statistical measures examined take very satisfactory values suggesting a good agreement between modeled and observed values. Both the levels and the variance in observed ozone values are well reproduced by the model.

Statistical regression analyses numerical model were implemented to investigate the contribution of meteorological conditions to ozone concentrations in year-round, summer, autumn, winter and spring. The results of this study show that there is a close relationship between changes in meteorological conditions and variations in ozone concentrations over the Campo Grande area. In year-round, summer, autumn, winter and spring, up to $78,73,75$ and $81 \%$ of long-term variations in peak ozone concentrations may be accounted for by changes in the seasonally averaged daily maximum temperatures and seasonally averaged wind speeds, humidity and precipitation. The results suggest that changes in meteorological conditions have significant impacts upon rising ozone concentrations in this area.

This study suggests that the model can be a useful tool for urban environmental analyses. However, since many processes and mechanisms affect ozone concentrations, it is necessary to develop a model that fully describes all of the chemical and physical processes involved in causing high pollution levels, including the complex interactions between topography, city building environments, land use, and anthropogenic emissions. 
5. References

Aires, C. B. Avaliação de contaminantes produzidos em locais de queimadas e transportados para regiões onde não se queima. 117 p. Tese (Doutorado em Geofísica Espacial - INPE, 2001).

Bloomfield P, Royle JA, Steinberg LJ, Yang Q. Accounting for meteorological effects in measuring urban ozone levels and trends. Atmos Environ 1996; 30:3067 -3077.

Brauer M, Brook JR. Ozone personal exposures and health effects for selected groups residing in the Fraser Valley. Atmos Environ 1997; 31(14): 2113 -2121.

Builtges P, Stern RM, Reynolds SD. The use of a photochemical dispersion model for several episodes in North Western Europe. In: Air Pollution Modelling and its Applications VI. New York: Plenum Press, 1988:431-450.

Bunzl K.Statistical procedures for the evaluation of radiological investigation. Selected examples. In: García León M, García Tenorio R, editors. Proceedings of the third International Summer School on Low Level Measurements of Radioactivity in the Environment: Techniques and Applications. Singapore: World Scientific, 1993. p.389-415.

Cox WM, Chu S-H. Assessment of interannual ozone variation in urban areas from a climatological perspective. Atmos Environ 1996; 30:2615 -2625.

Dapeng XU, YAP D, Taylor PA. Meteorologically adjusted ground level ozone trends in Ontario. Atmos Environ 1996;30(7):1117 -1124.

Di Carlo, P., Pitari, G., Mancini, E., Gentile, S., Pichelli, E., Visconti, G., 2007. Evolution of surface ozone in central Italy based on observations and statistical model. Journal of Geophysical Research-Atmospheres 112, art. No. D10316.

Fearnside, M. P. A água de São Paulo e a Floresta Amazônica. Ciência Hoje, Volume de abril de 2004; $63-65$.

Finlayson-Pitts BJ, Pitts JN. Atmospheric Chemistry: Fundamental and Experimental Techniques. New York: Wiley, 1986.

Fisch, G., Marengo A. J, Nobre C. A., Clima na Amazônia. ACTA Amazônica, Vol. 28 1998; 101-126.

Heck $\mathrm{P}$. Les solutions posibles au problème de la pollution atmosphérique en Europe. Pollution Atmosphérique 1989; 122:161 -167.

Hubbard, M.C., Cobourn, W.G.,. Development of a regression model to forecast ground-level ozone concentration in Louisville, KY. Atmospheric Environment 32, 2637-2647,1998.

Korsog PE, Wolff GT. An examination of ozone urban trends in the northeastern U.S. (1973-1983) using a robust statistical method. Atmos Environ B 1991; 25:47 $-57$.

Lelieveld, J., Crutzen, P.J., Influences of cloud photochemical processes on tropospheric ozone. Nature 343, 227-233, 1990.

Lima, C. M., Manutenção da circulação atmosférica sobre a América do Sul. 222 p. Tese (Doutorado em Meteorologia - INPE 1996).

Lippmann M. Health effects of tropospheric ozono. Environ Sci Technol 1991; 25:1954 -1962.

Millán MM, Artin ano B, Alonso LA, Fernández Tapier R, Goberna G. Mesometeorological cycles of air pollution in the Iberian Peninsula and Southern Mediterranean area. Transport and Transformation of Air Pollution in the Atmosphere. EUROTRAC Symposium. Netherlands: Academic Press, 1991.

Millán MM, Salvador R, Mantilla E, Artíano B. Meteorology and photochemical air pollution in southern Europe: experimental results from EC research projects. Atoms Environ 1996; 30:1909 -1924.

Pryor SC. A case study of emission changes and ozone responses. Atmos Environ 1998; 32:123 -131.

Rydley BA. Recent measurements of oxidized compounds in the troposphere. Atmos Environ 1991;25A:1905 -1926. 
Saunders SM, Jenkin ME, Derwent RG, Pilling MJ. WWW site of a master chemical mechanism for use in tropospheric chemistry models. Atmos Environ $1997 ; 31: 1249$.

Schenone G, Lorenzini G. Effects of regional air pollution on crops in Italy. Agric Ecosystem Environ 1992; 38:51 -59.

Staehelin J, Smith W. Trend analysis of tropospheric ozone concentration utilizing the 20 year data set of ozone balloon soundings over Payerne (Switzerland). Atmos Environ 1991; 25A: $1739-1757$.

Staehelin J, Thudium J, Buehler R, Voltz-Thomas A, Graber W. Trends in surface ozone concentrations at ARISA (Switzerland). Atmos Environ 1994; 28(1): 75 -87.

Souza, A. Distribuição espacial da relação precipitação/número de dias de chuvas em Campo Grande- MS. In: SEMINÁRIO DE RECURSOS HÍDRICOS DA BACIA HIDROGRÁFICA DO PARAÍBA DO SUL, 2, 2009. Anais...Taubaté: 2009.

Tadano, Y. de S.; UGAYA, C. M. L.; FRANCO, A. T. Método de regressão de Poisson: metodologia para avaliação do impacto da poluição atmosférica na saúde populacional. Ambient. soc. [online]. 2009, vol.12, n.2, pp. 241-255.

UN-ECE. Final Draft Report of the ECE Critical Levels Workshop. Germany: Bad Harzbourg, 1988.

Vecchi R, Valli G. Ozone assessment in the southern part of the Alps. Atmos Environ 1999; 33:97 -109.

Vianello, R. L., \& Alves, A. R., 1991 - Meteorologia Básica e Aplicações.

Volz A, Kley D. Evaluation of the Montsouris series of ozone measurements made in the nineteenth century. Nature 1988;323:240 -242.

WHO. Air Quality Guideliness for Europe. European Series, 23, Copenhagen.1987.

Zierock KM, Bartaire JG. The role of dispersion models in the EC poling on photochemical oxidants. Air Pollutions and its Applications VI. New York: Plenum Press, 1988.

Zurita E, Castro M.A Statistical analysis of mean hourly concentrations of surface ozone at Madrid (Spain). Atmos Environ 1983; 17:2213 - 2220. 